\title{
Utilizing wild foraging ecology information to provide captive primates with an appropriate diet
}

\author{
BY SUSAN D. CRISSEY AND LINDA S. PRIBYL
}

The Daniel F. and Ada L. Rice Conservation Biology and Research Center, Chicago Zoological Society, Brookfield Zoo, Brookfield, IL 60513, USA

Maintaining some species of primates in captivity has been difficult. Current data show that of the howler monkey species (Alouatta spp.), only black howlers (Alouatta caraya) are maintained and breed in significant numbers in captivity. The other howler monkey species have a poor record. For example, there were only twenty-three red howlers (Alouatta seniculus) recorded with the International Species Information System (ISIS; 12101 Johnny Cake Ridge Road, Apple Valley, MN 55124-8151, USA) in 1994, reflecting the population status in North America, Central America and much of Europe. Of these animals only fifteen were captive born. Of all nineteen mantled howlers (Alouatta villosa) eight were captive born (information available from ISIS in 1994). This status indicates a failure of these species to thrive in captivity. Other leaf-eating monkeys such as colobus (Colobus guereza), langurs (Pygathrix nemaetis) and proboscis (Nasalis larvatus) have been considered delicate species and were short lived (Hollihn, 1973). Nutritional problems such as wasting disease, $\mathrm{Zn}$ and vitamin $\mathrm{C}$ deficiencies, also, were experienced with the insectivorous marmosets (Chadwick et al. 1979; Fluer \& Zucker, 1989). While captive management, including nutrition, has been substantially improved in recent years, there remain challenges in providing good nutrition to captive primates.

One of the most-well-studied areas of nutrition is the nutrient requirements of human subjects. As more is discovered about human nutrition it is evident that providing adequate nutrition to human subjects is a complex process and includes the forms and functions of many nutrients that are inter-related. Among non-human primate species it is probable that some of the form and function issues also are relevant. In addition, there are vast differences among primate species which can have a significant impact on nutritional status and captive feeding approaches. Since feeding strategies, gut morphology, and nutrient requirements may be unique to a species, each species provides challenges to zoological institutions providing for the nutrition of these animals. The array of strategies includes folivorous primates with capacious guts for fermentation, omnivorous primates with comparatively simple guts, more like that of the human subject, to small insectivorous primates with specific adaptations to their way of life. Thus, information relevant to all aspects of animal feeding and probable nutrient requirements must be considered in order to provide captive primates with appropriate diets.

Information describing the feeding strategies of free-ranging primates with respect to nutrient intake is incomplete. Primate species occupy numerous niches and consume a variety of foods (Chapman \& Chapman, 1990). Each food niche is affected by many factors, which include climate, physical structure of the habitat, predators, co-consumers, distribution, arrangement and availability of food, and physical characteristics of food items (Sailer et al. 1985; Muruthi, 1988; Whitten, 1988). Foraging data are gathered by observational studies of free-ranging animals. The factors that affect foraging ecology also contribute to the challenge of collecting free-ranging primate feeding data (Norris, 1988). In general, data collection includes observation of time spent feeding and the types of food consumed by a selected group of animals. Intake may be determined by estimating bite size 
and number of bites with time spent feeding (Williamson et al. 1990). While valuable, these observations do not describe a quantified measurement of food intake. Additionally, the nutrient content of food consumed often is not determined in these types of studies. Thus, nutrient intake of free-ranging primates remains unknown for many species.

Studies of gut morphology are relatively descriptive, although may be limited in the number of individuals of a species examined. Differences among sub-species, if any, often remain to be identified. Examination of morphology and physiology at the functional and cellular level is scarce.

A number of studies describe requirements for some nutrients with respect to specific primate species, but the compilation of this information is outdated. The National Research Council (NRC; 1978) publication which attempted to describe the nutrient requirements of non-human primates, requires updating. This publication falls far short of providing information for many nutrients and many primate species. Factors such as activity, growth, pregnancy and lactation, which may affect nutrient requirements or utilization, also must be considered (Oftedal \& Allen, 1996). However, it is likely that in general, primates have similar qualitative nutrient requirements for tissue metabolism and the NRC (1978) publication remains a primary source of information.

Because the compilation of human nutrient requirement information is more current (NRC, 1989) compared with the publication for non-human primates (NRC, 1978), human requirements may be used to better understand non-human primate needs. Also, human nutrient requirements offer a margin of safety to allow for variability among individuals (NRC, 1989), while the non-human primate publication (NRC, 1978) indicates an undefined 'acceptable' performance. The two publications, however, are not directly comparable because the data are presented differently. Nutrient requirements for non-human primates are expressed on a DM basis. This provides for consistent comparison of the nutrient content of food items because it eliminates the diluting effect of water. The recommended daily allowances (RDA) for human primates are expressed on an 'as consumed' basis. In practical terms, foods are fed to captive animals on an 'as consumed' basis and include all nutrients with the moisture. Thus, to compare requirements data must be converted to either a DM basis or to an 'as consumed' basis. However, when providing a diet to an individual animal, the total quantity of nutrients fed or consumed daily can be calculated regardless of how the data are expressed.

\section{FOLIVORY}

The herbivorous folivores are among the most interesting specialized non-human primate feeders. Unlike the other primates, these primates can subsist on fibrous plant matter consisting largely of leaves. Leaf-eaters such as colobines, langurs and howler monkeys have guts which are adapted for this feeding strategy.

Colobus and Presbytis spend most of their arboreal life feeding on plant parts that include leaves, flowers and seeds (Oates et al. 1980). The proboscis monkey, a colobine, consumes almost half its diet as leaves (Yeager et al. 1997). Leaves utilized by proboscis monkeys contained about $90 \mathrm{~g}$ protein $/ \mathrm{kg}$ DM with about $350 \mathrm{~g}$ fibre $/ \mathrm{kg}$ DM (aciddetergent fibre; Oates et al. 1980). Other colobines may spend less than $40 \%$ of their time consuming mature leaves and more than $50 \%$ of their time feeding on seeds, fruits and flowers (Chivers, 1994). It was found that in general, of the proboscis and colobus monkeys, Colobus guereza are more folivorous than presbytis which tend to be more 
frugivorous (Chivers, 1994). Fruits consumed by colobines averaged $78 \mathrm{~g}$ protein $/ \mathrm{kg}$ (Waterman \& Kool, 1994). However, leaves form a major portion of the diet and the plant material consumed by these folivores is relatively fibrous compared with the total diet of most other primates. While still considered folivores, there are exceptions to the total herbivory. For example, hanuman langurs (Presbytis entellus) have been observed to consume some insects along with their mainly herbivorous diet (Srivastava, 1991).

The selection of a folivorous diet is related to increased gut complexity (Chivers, 1994). Colobine monkeys and Asian langurs (Trachypithecus spp.) are unique in that they have a more specialized gut than most primates (Stevens \& Hume, 1995). Colobines have a large and compartmentalized stomach. Asian langurs have stomachs similar to those of the colobines, but have longer small and large intestines and a more-developed caecum (Stevens \& Hume, 1995). Large stomachs and moderate length small and large intestines are adaptations to a diet high in fibre. This type of digestive tract morphology aids in the digestion of high-fibre foods by allowing for an increased passage rate of digesta through the gut (Chivers \& Hladik, 1980). Microbes in the gut ferment the proteins and long-chain carbohydrates found in plant materials to produce volatile fatty acids and essential amino acids, which in turn can be utilized by the host. It has been shown that the lysozymes present in colobine monkeys are similar to those in ruminants such as cattle (Stewart et al. 1988), indicating that microbial populations may have similar importance to digestion in colobines as they do in ruminants. It has been demonstrated that when fed a manufactured biscuit diet, the colobus monkey can digest $87 \%$ of the DM and $81 \%$ of the fibre fractions (neutral-detergent fibre (NDF): hemicellulose, cellulose and lignin). It was remarked that these were higher digestibilities than predicted with ruminant species (Watkins et al. 1985). These values are slightly higher than those from a similar study conducted with colobus and langurs which showed DM digestibilities ranging from 77 to $82 \%$ (Edwards, 1995).

The howler monkeys are also folivorous. The brown howler (Alouatta fusca) diet comprised (\%): leaves 73 , flowers 12 , fruits 5 . While young leaves mainly were consumed, it was indicated that these were the most-readily-available food items (Chiarello, 1994). Red howlers consumed over $50 \%$ of their diet as leaves, with fruit at about $30 \%$ and flowers over $15 \%$. The majority of leaves consumed by red howlers were mature leaves with a high fibre content (Crissey et al. 1989). The fibre composition of the diet consumed by red howlers was comparable with that of lucerne (Medicago sativa) hay (Crissey et al. 1989). Mantled howlers also were observed to be folivores but consumed the majority of leaves as new leaves (Smith, 1977; Milton, 1981).

Although they consume a herbivorous diet like the colobines, the gut of howler monkeys is considerably different from that of the colobine monkeys. Howler monkeys possess a moderately-sized stomach with no compartmentalization. Their capacity for fibre fermentation is in the lower gut, with an expanded caecum and capacious large intestine (Crissey et al. 1989). While they consume a fibrous diet, like other hindgut fermenters, their digestive strategy is more likely to decrease the passage rate of digesta in the total gut, which lowers digestive capacity compared with foregut fermenters like the colobines. It follows that the DM digestibility of manufactured biscuits in red howlers ranged from 62 to $69 \%$ in these hindgut fermenters (Edwards, 1995). This strategy allows fermentation in the lower gut, but the nutrients from this portion of the gut may have limited availability to the animal (Van Soest, 1996).

Thus, both the colobine species and howler species exploit leaves as their main source of food, but their digestive strategies differ. These factors may influence nutrient requirements among folivorous species. Also, the nutrient requirements of folivores may be 
different from those of other primate species with different foraging strategies and gut morphologies.

\section{INSECTIVORY}

Some of the very small primates, such a callitrichids (marmosets and tamarins, body mass ranging from 105 to $700 \mathrm{~g}$; Garber, 1992), consume insects as a large portion of their diets in the wild. However, there are foraging differences among, and even within, these species. While the primary adaptation is insect feeding, food selection among free-ranging callitrichid species varies from insects and fruits in the larger animals to insects and exudates (gums, saps and latex) in the smaller animals (Garber, 1992).

Emperor tamarins (Saguinus imperator) consume primarily insects and fruits. When fruit is scarce, emperor tamarins have been noted to be intense nectar feeders (Terborgh, 1983). But nectar cannot support maintenance and they may lose up to $15 \%$ of their body weight when consuming large quantities of nectar (Rosenberger, 1992). Moustached (Saguinus mystax) and saddle-backed (Saguinus fuscicollis) tamarins spend up to $31 \%$ of feeding time consuming nectar during the dry season (Garber, 1988). Saddle-backed and moustached tamarins consume prey and water from bromeliads (Nickel \& Hyemann, 1996) as do golden lion tamarins (Leontopithecus; Garber, 1992). Some may consume up to thirty-eight species of insects (Nickel \& Heymann, 1996). Moustached tamarins, which consume about $14 \%$ of their diet as insects, also eat fruit seeds. However, the seeds are passed primarily undigested (Heymann, 1992), limiting their contribution of nutrients. Arboreal pygmy marmosets (Cebuilla pygmaea) spend $67 \%$ of their total feeding time in the procurement and investigation of exudates and $33 \%$ of feeding time foraging for insects. Fruit, buds, flowers and nectar constitute a minor portion of the diet (Ramirez et al. 1977).

Dentition of callitrichids is associated with their feeding strategy and is categorized as: short-tusked, for gouging bark (marmosets), and long-tusked, similar to other primates (tamarins; Ferrari \& Martins, 1992). Gut morphology of callitrichids has been associated with the extent to which a species consumes exudates, specifically gums. It is thought that for increased digestion of gums, a more complex gut is beneficial. Common marmosets (Callithrix jaccus) which are largely exudate feeders possess a large complex caecum with internal ribbon-like structures (Garber, 1992). Callithrix emiliae also have a large complex caecum to help process gums (Ferrari \& Martins, 1992). These gut features are less well developed in the golden lion tamarin (Garber, 1992). Digestibility of gums by galagos (Galago senegalensis braccatus), an African gum-eating prosimian, averaged $790 \mathrm{~kJ} / \mathrm{MJ}$ total energy (Nash, 1989). The digestible energy of an artificial diet fed to a variety of callitrichids ranged from $710-860 \mathrm{~kJ} / \mathrm{MJ}$ total energy where the smaller-bodied species possessed decreased energy digestibility when compared with species of larger body size. The exception to this was the pygmy marmoset which had the smallest body size and the ability to digest energy at $840 \mathrm{~kJ} / \mathrm{MJ}$ total energy (Power, 1991).

Thus, it appears as though the callitrichid gut morphology may allow them to obtain considerable nutrients from the insects and exudates consumed. As observed, the callitrichid species utilize insects and exudates as their main sources of food but their digestive strategies differ among species. Like the folivores, these factors may influence nutrient requirements among callitrichid species. Again, these specialists may have nutrient requirements different than other primate species with different foraging strategies and gut morphologies. 


\section{FOOD COMPOSITION}

Studies of foraging strategies do not often include an examination of food nutrient composition. Food composition studies can provide data about the types and amounts of nutrients available in foods consumed by free-ranging primates. Studies of food composition may indicate the motivation behind diet selection. For example, it has been thought that free-ranging primates select foods such as immature leaves, some fruits and insects based on their protein content (Oates et al. 1980; Calvert, 1985; Yeager et al. 1997). However, this theory has not been proved consistently (Oftedal, 1992).

There has been considerable interest in diet selection with respect to secondary plant compounds such as tannins, especially with folivorous monkeys (Oates et al. 1977, 1980; Moreno-Black \& Bent, 1982; Yeager et al. 1997). For example, colobus are able to consume small amounts of plants containing toxic secondary plant compounds (Waterman \& Kool, 1994). These compounds can decrease the gut flora, deactivate enzymes in the gut or act as a toxin (Kavanagh, 1983). However, it has been suggested that some primates will select particular food items based on medicinal qualities and, thus, use secondary metabolites to their advantage (Wrangham \& Goodall, 1989).

Reasons for selection of particular food items may be of importance with regard to ecological concerns, but what is crucial to captive animal nutrition is the nutrient profile of the foods consumed. It should be noted that the nutrient and metabolite content of plant parts can be affected by habitat, environmental conditions and maturity of the plant among other factors (Van Soest, 1996). For example, mature leaves often are higher in fibre than new leaves (Kay \& Davies, 1994).

Additionally, chemical analyses alone may not indicate the availability of the nutrient to the animal. For example, there may be an overestimation of protein available in insects because the $\mathrm{N}$ found on analysis is actually bound to chitin in the exoskeleton and may be unavailable to the animal (Allen, 1989; Dierenfeld, 1993).

The requirement for health is a requirement for nutrients in the food, not the food per se. However, incorporating data about the foraging strategy and gut morphology of the primate in formulating the captive primate diet is fundamental. This information may provide essential clues as to the possible unique requirements of each species, how available the nutrients may be to the animal, and how the animal may utilize the available nutrients.

By comparing the nutrient composition of the foods consumed by free-ranging species with that available to zoological institutions, the diet offered to captive primates can be determined. One of the challenges is that most of the food items consumed by non-human primates in the wild are unavailable commerically. Produce grown for human consumption which is fed routinely to captive primates may not have the same nutrient profile as those types of items consumed in the wild. This is because produce such as fruits and vegetables available to captive primates may be considerably higher in water, lower in fibre and more readily digestible than the natural diet.

As mentioned previously, the fibre level present in the diet of the free-ranging red howler monkey is similar to that of lucerne hay (Crissey et al. 1989) which is fed often to horses. In comparison, the fibre level of celery (Apium graveolens), a leafy vegetable available to institutions (United States Department of Agriculture, 1984), is considerably less than that of the natural diet of howlers (Crissey et al. 1989). Likewise, it was found that captive Asian colobine monkeys consumed diets lower in fibre and higher in protein than these animals are likely to consume in the wild (Nijboer \& Dierenfeld, 1996). The same type of information was recorded for captive gorillas (Gorilla gorilla gorilla) where the captive animal diets contained NDF levels between 32 and $142 \mathrm{~g} / \mathrm{kg}$ (Crissey \& Allen, 
1987) compared with free-ranging gorillas consuming from 400 to $900 \mathrm{~g} \mathrm{NDF} / \mathrm{kg}$ (Calvert, 1985). Table 1 illustrates comparisons of crude protein $(\mathrm{N} \times 6.25)$, NDF and moisture levels in selected fruits and vegetables with those of fruits consumed by free-ranging gorillas. The NDF values of common selected produce items ranged between 120 and $170 \mathrm{~g} / \mathrm{kg}$ compared with those of the fruits consumed by gorillas in the wild which ranged between 550 and $710 \mathrm{~g} / \mathrm{kg}$, on a DM basis. The moisture content was slightly higher in the cultivated produce compared with the fruit consumed by free-ranging gorillas. It is evident that, in general, the fruits consumed by free-ranging gorillas contain considerably more $\mathrm{NDF}$, somewhat at the expense of moisture, than commerically-cultivated produce found in North America.

Browse plants may be available to institutions housing captive primates, but for zoos in temperate climates these may be limited to seasonal availability. Leaves of browse plants in the New York (USA) area were found to contain between 200 and $390 \mathrm{~g} \mathrm{NDF} / \mathrm{kg} \mathrm{DM}$ in summer months and $280-730 \mathrm{~g} / \mathrm{kg}$ DM in the autumn (Nijboer \& Dierenfeld, 1996). Thus, it is possible that some browse plants may resemble more closely the lower protein and higher fibre levels of plant parts consumed by folivorous primates than leafy vegetables. Comparison of crude protein and NDF levels in selected commerically-cultivated leafy vegetables, commerically-available hays, naturally-occurring uncultivated leaves used as browse, and leaves consumed by folivorous primates is shown in Table 2 . This comparison demonstrates that there is considerable overlap in protein and NDF levels among food items. Given the range of protein and NDF consumed by folivorous primates, consumption of highly-fibrous leafy vegetables, browse species and even hay may simulate the protein and fibre composition of natural diets.

For callitrichids which consume insects as a large part of their diet, insects can provide a source of protein and fat. The array of insect types and insect stages consumed by freeranging insectivorous primates may be considerable (Nickel \& Heymann, 1996). Data on the nutrient composition of insects consumed by these insectivores are scarce. In general, nymph and larvae stages have a higher fat content than other life stages (Dierenfeld, 1993). Small larvae consumed by free-ranging aye-aye (Daubentonia madagascariensis), for example, contained $565 \mathrm{~g}$ crude protein $/ \mathrm{kg}$ DM and large larvae contained $307 \mathrm{~g} / \mathrm{kg}$ DM. Comparison of lipid content was 333 and $444 \mathrm{~g} / \mathrm{kg}$ DM for small and large larvae respectively (Sterling et al. 1994). Insects may vary in nutrient content depending on the

Table 1. Comparison of protein and neutral-detergent fibre levels $(\mathrm{g} / \mathrm{kg} \mathrm{DM})$ in selected commerically-available fruits and vegetables compared with fruits consumed by gorillas (Gorilla gorilla gorilla)

\begin{tabular}{lccc}
\hline \hline Item & Protein & Neutral-detergent fibre & Moisture \\
\hline Apple* & 20 & 170 & 850 \\
Banana $\dagger$ & 40 & 120 & 740 \\
Pear $\dagger$ & 20 & 170 & 840 \\
Carrot $\dagger$ & 80 & 120 & 880 \\
Tetrapleura tetraptera $\ddagger$ & 40 & 550 & 540 \\
Solanum sp. $\ddagger$ & 140 & 550 & 770 \\
Desplatsia sp. $\ddagger$ & 40 & 600 & 610 \\
Grewia coriacea $\ddagger$ & 40 & 680 & 680 \\
Aframomum hanburi, mature $\ddagger$ & 70 & 710 & 700 \\
\hline
\end{tabular}

* Souci et al. (1981).

† United States Department of Agriculture (1984).

$\ddagger$ Fruits consumed by gorillas (Calvert, 1985). 
Table 2. Comparison of protein and neutral-detergent fibre levels ( $\mathrm{g} / \mathrm{kg} \mathrm{DM}$ ) in selected leafy vegetables, browse leaves found in the USA, dried forage, and leaves consumed by the folivorous monkeys: the Indian leaf monkey (Presbytis johnii), the proboscis monkey (Nasalis lavartus) and the red howler monkey (Alouatta seniculus)

\begin{tabular}{llc}
\hline \hline Item & Protein & Neutral-detergent fibre \\
\hline Celery (Apium graveolens)* & 120 & 170 \\
Spinach (Spinacia oleracea) $\dagger$ & 300 & 470 \\
Legume hay (lucerne; Medicago sp.) $\$$ & 190 & 370 \\
Grass hay (timothy; Phleum pratense) $\ddagger$ & 80 & 610 \\
Browse leavesई & $90-190$ & $200-730$ \\
Leaf monkey leaves $\|$ & $70-210$ & $270-610$ \\
Proboscis monkey leaves $\|$ & 100 & 430 \\
Red howler leaves $\|$ & - & 560 \\
\hline \hline
\end{tabular}

* United States Department of Agriculture (1984).

$\dagger$ Souci et al. (1981).

$\ddagger$ Hay values analysed at Brookfield Zoo, Brookfield, IL, USA).

§ Browse leaves (Nijboer \& Dierenfeld, 1996).

|| Leaves for: leaf monkey (Oates et al. 1980); proboscis monkey (Yeager et al. 1997); red howler (Crissey et al. 1989).

diet of the insect itself. It has been found that if crickets (Acheta domestica) are fed a high$\mathrm{Ca}$ diet, their total Ca content increases because of gut fill (Allen, 1989). It is presumed that this may occur also in the wild.

Insects available commerically are limited in species and stage of development, thus the array of insects consumed by primates in the wild is not available to captive animals. Also, the diets that the commercial insects consume can be controlled. If controlled well, nutrients can be offered which can fortify the insects as a nutrient source, as is the situation with $\mathrm{Ca}$ (Allen, 1989). The composition of invertebrates available commerically, if used as an example for basic nutrient composition of insects in the wild, shows crude protein estimates ranging from $310 \mathrm{~g} / \mathrm{kg}$ DM for wax moth (Galleria mellonella) larvae to 700 $\mathrm{g} / \mathrm{kg} \mathrm{DM}$ for fruit flies (Drosophila spp; Table 3). Lipid levels as measured by diethyl ether extract were more variable, ranging from $70 \mathrm{~g} / \mathrm{kg}$ DM for earthworms (Lumbricus spp.) to $610 \mathrm{~g} / \mathrm{kg}$ DM for wax moth larvae. These data show that the analysed invertebrates, except the earthworm, contained an inverse Ca: P (Allen \& Oftedal, 1994).

Nutrient data are not available for nectar and gums utilized by many callitrichids. Exudates consumed by the Panamanian tamarin (Saguinus oedipus geoffroyi) were recorded to contain between 20 and approximately $100 \mathrm{~g}$ protein $/ \mathrm{kg}$, depending on the

Table 3. Composition ( $\mathrm{g} / \mathrm{kg} \mathrm{DM}$ ) of invertebrates commonly fed to zoo animals. (Adapted from Allen \& Oftedal, 1994)

\begin{tabular}{lccccc}
\hline & $\begin{array}{c}\text { Mealworm } \\
\text { (Tenebrio } \\
\text { molitor) } \\
\text { larvae }\end{array}$ & $\begin{array}{c}\text { Fruitfly } \\
\text { (Drosophila } \\
\text { spp.) }\end{array}$ & $\begin{array}{c}\text { Cricket } \\
\text { (Acheta } \\
\text { domestica) }\end{array}$ & $\begin{array}{c}\text { Wax moth } \\
\text { (Galleria } \\
\text { mellonella) } \\
\text { larvae }\end{array}$ & $\begin{array}{c}\text { Earthworm } \\
\text { (Lumbricus } \\
\text { spp.) }\end{array}$ \\
\hline $\begin{array}{l}\text { Crude protein } \\
\quad(\mathrm{N} \times 6.25)\end{array}$ & 480 & 700 & 660 & 310 & 650 \\
Lipid & 360 & 130 & 170 & 610 & 70 \\
Ash & 46 & 45 & 61 & 18 & 103 \\
Ca & 0.7 & 1.0 & 1.8 & 3.9 & 9.0 \\
$\mathrm{P}$ & 0.6 & 10.5 & 8.6 & & 3.9 \\
\hline \hline
\end{tabular}


season. Ca content ranged from 3 to $7 \mathrm{~g} / \mathrm{kg}$ with a $\mathrm{Ca}: \mathrm{P}$ value ranging from $31: 1$ to $142: 1$ (Garber, 1984). Acacia gum, consumed by galagos is available commercially (Nash, 1989). This is primarily a source of carbohydrate, including arabinose, galactose, rhamnose, and glycuronic acid (Windholz, 1976). Commercially-available nectar contains (g/kg DM): protein 20, Ca 0.4, P 0.4 (United States Department of Agriculture, 1984). Given the information available, it can be deduced that the nutrient content of insects, gums, and nectar would contribute to a complementary nutrient profile when consumed as components of a total diet.

Often a variety of foods have been offered in marmoset research colonies. Items included some type of commerical diet, with some other foods including insects, small vertebrates and fruit and vegetable produce (Clapp \& Tardif, 1985). The level of protein reported as adequate was $200 \mathrm{~g} / \mathrm{kg}$ DM with a comment that this may be above true requirement levels. Lipid levels were about $70 \mathrm{~g} / \mathrm{kg} \mathrm{DM}$, with carbohydrate at $53 \mathrm{~g} / \mathrm{kg}$ DM. It was stated that diets such as these almost eliminated the problem of marmoset wasting syndrome.

Compared with levels of protein and lipids in insects, the levels stated previously for research colony diets are considerably lower. Thus, compared with the folivorous primates, the primarily insectivorous captive primates may be consuming diets less nutrient dense with respect to protein and lipid than much of their natural diet.

Two factors often overlooked when examining diets of free-ranging animals and applying that information to the formulation of captive primate diets are: (1) the impact of 'incidental' ingestion, (2) the chemical form of a particular nutrient. Incidental ingestion may be as obvious as the observation that moustached tamarins have been seen to consume soil, it was presumed this was for its mineral content (Hartmann \& Hartmann, 1991). Consuming minerals in this fashion may complement the limited mineral content of insects. Observations on free-ranging aye-aye found them to consume a diet relatively low in $\mathrm{Ca}$. For example, the quantity of $\mathrm{Ca}$ in a particular fungus, their highest source of that mineral, was only $2 \mathrm{~g} / \mathrm{kg}$ (Sterling et al. 1994). As the aye-aye bores through branches for insects, it may consume gums and saps that may contain additional $\mathrm{Ca}$ as well as carbohydrate (Crissey et al. 1995). Colobus monkeys (Procolobus kirkii) have been seen to consume charcoal, but the significance of this has not been investigated (Struhsaker $e t$ al. 1997). Consumption of the incidental insect by the folivorous monkey or the nutrients contained in the bromeliad liquid from which callitrichids catch and consume their prey may provide significant nutrients to a diet otherwise deficient in some nutrients.

The chemical form of a particular nutrient available from items consumed by freeranging primates may affect the availability of that nutrient for metabolism. This hypothesis is not well researched, but there are a few examples and questions which may lead to more examination. One topic which has generated investigation is vitamin $D$. New World primates are primarily able to utilize cholecalciferol, while Old World primates can utilize both ergocalciferol and cholecalciferol. It has been shown that callitrichids may require higher levels of cholecalciferol than other New World primates because of a targetorgan receptor resistance to the active form of the vitamin (Takahashi et al. 1985). Goeldi's monkeys (Callimico geoldii) of the New World primates, described as intermediate to callitrichids and cebids, were fed on diets with vitamin D levels appropriate for callitrichids. This population of animals suffered from renal disease and it was thought that vitamin $\mathrm{D}$ levels may have been a contributing factor. When compared with human circulating levels, 1,25-dihydroxyvitamin $\mathrm{D}$ was consistently elevated while 25hydroxyvitamin D was not (Crissey et al. 1996). These are examples where the form and possibly the quantity of the vitamin is important to nutritional status. However, 
problems continue to exist, especially with respect to leaf-eating monkeys and nursing infants (Morrisey et al. 1994). Thus, the remedy to the problem may not be as simple as the difference between dietary ergocalciferol and cholecalciferol. It has been shown that ergocalciferol originates from plant food sources, while cholecalciferol is primarily found in animal products (Miller \& Norman, 1984). It has been discovered, however, that a number of plants contain active cholecalciferol compounds (Prema \& Raghuramulu, 1994). This provides evidence that not only is cholecalciferol present in plants, but also its active metabolites: 25-hydroxycholecalciferol and 1,25-dihydroxycholecalciferol, giving rise to the question once again that a particular form of the vitamin or possibly even the metabolite is needed in the diet for some species. Additionally, since sunlight can play a major role in vitamin D status, evolution of a dependence on dermal conversion is also in question. Thus, the problem may be more complex than originally thought and given that this is just one example, there may be many questions about the availability and form of any number of nutrients which are yet to be investigated.

In the wild, animals consume a somewhat varied diet which is thought to allow for selection of a diet which meets their requirements. While there may be natural constraints, in times of abundance, this statement is probably correct. Similarly, a diet for captive primates must meet all the nutrient requirements of the species, while providing food choices to complement gut morphology and feeding strategy. Given that for many primate species the foods cultivated for human use generally are unlike those in the natural diet, the challenge is to develop an appropriate and palatable diet using available food items.

There are a number of products manufactured for captive primates. In general, these are formulated to meet the nutrient requirements published in 1978 (NRC, 1978). A comparison of the nutrient content for several manufactured primate foods utilized in the UK and the USA shows variations compared with the foraging strategies of the animals they are intended to feed (Table 4).

In general, there appear to be two product categories, $230-280 \mathrm{~g}$ protein $/ \mathrm{kg}$ and $180 \mathrm{~g}$ protein $/ \mathrm{kg}$. Interestingly, the $230 \mathrm{~g}$ protein $/ \mathrm{kg}$ diet is intended for marmoset species. Also, the 'leaf-eater' and 'high-fibre' diets are between 130 and $140 \mathrm{~g}$ crude fibre/kg DM. While the measurements for crude fibre and NDF are not directly comparable, these levels can be considered much lower than those the leaf-eating primates would be consuming in the wild. Thus, it appears that while there is an acknowledgement to formulate diets in line with

Table 4. Nutrient composition $(\mathrm{g} / \mathrm{kg} D M$ ) of some manufactured primate foods used in the $U K$ and the USA*

\begin{tabular}{|c|c|c|c|c|c|c|c|c|}
\hline \multirow[b]{2}{*}{ Food... } & \multicolumn{4}{|c|}{ UK } & \multicolumn{4}{|c|}{ USA } \\
\hline & Leafeater & Range & Old World & New World & High-protein & New World & High-fibre & Marmoset \\
\hline $\begin{array}{r}\text { Crude protein } \\
(\mathrm{N} \times 6.25)\end{array}$ & 250 & 260 & 180 & 280 & 280 & 280 & 180 & 230 \\
\hline Crude fat & 55 & 59 & 68 & 83 & 56 & 47 & 59 & 79 \\
\hline Crude fibre & 140 & 50 & 50 & 40 & 40 & 50 & 130 & 20 \\
\hline Ash & 80 & 70 & 60 & 120 & 70 & 60 & 80 & 60 \\
\hline $\begin{array}{l}\text { Vitamin A } \\
\text { (mg/kg DM) }\end{array}$ & 6.6 & $11 \cdot 1$ & 6.9 & 9.9 & $11 \cdot 7$ & 6.6 & 13.5 & $10 \cdot 2$ \\
\hline $\begin{array}{l}\text { Vitamin D } \\
(\mathrm{mg} / \mathrm{kg} \mathrm{DM})\end{array}$ & 82 & 305 & 52 & 323 & 183 & 138 & 245 & 580 \\
\hline $\mathrm{Ca}$ & $1 \cdot 1$ & 1.2 & 0.8 & 2.4 & $1 \cdot 1$ & $1 \cdot 1$ & $1 \cdot 1$ & 0.8 \\
\hline$P$ & 0.7 & 1.0 & 0.6 & 1.6 & 0.7 & 0.7 & 0.6 & 0.6 \\
\hline
\end{tabular}

* Nutrient analyses provided by manufacturers. 
primate foraging ecology, comparison of nutrient content with the information gathered on foraging strategies and gut morphologies of primate species illustrates that the products available may not provide for the variation needed. However, some specific needs have been addressed with these manufactured diets. As Table 4 illustrates, vitamin D levels are increased in the marmoset diet, most probably in response to the studies which showed a target-tissue resistance to vitamin D. Since the manufactured diets contain a wide array of nutrients, they still are appropriate for inclusion in the primate diet. This is because items such as browse, and commercially-available fruit and vegetable produce, seeds, gums, nectar and invertebrates do not individually provide all the nutrients the species may require.

Thus, the task remaining is to formulate a diet utilizing resources available. Usually, a combination of a palatable manufactured diet with appropriate additional food choices to complement the foraging ecology and gut morphology of the species is attempted. The objective is to add appropriate items to the diet and to utilize the manufactured diet without diluting essential nutrients provided by either.

In conclusion, foraging strategies and gut morphology play a large role in food item selection and nutrient utilization in free-ranging primates. While the examples presented do represent some limited extremes, this one order of animals represents almost every combination of the myriad of both foraging strategies and complementary gut morphology. Utilization of this knowledge is essential in formulating an appropriate diet for captive primate species. Much information is yet to be learned and as more is discovered about the nutritional strategies of these animals, application to other species including man, may be possible.

\section{REFERENCES}

Allen, M. E. (1989). Nutritional aspects of insectivory. Doctoral Dissertation, Michigan State University.

Allen, M. E. \& Oftedal, O. T. (1994). The nutrition of carnivorous reptiles. In Captive Management and Conservation of Amphibians and Reptiles, pp. 78-79 [J. Murphy, K. Adler and J. T. Collins, editors]. Ithaca, NY: Society for the Study of Amphibians and Reptiles.

Calvert, J. (1985). Food selection by Western gorillas (G.g. gorilla) in relation to food chemistry. Oecologia 65 , 236-246.

Chadwick, D., May, J. \& Lorenz, D. (1979). Spontaneous zinc deficiency in marmosets. Laboratory Animal Science 29, 482-485.

Chapman, C. \& Chapman, L. (1990). Dietary variability in primate populations. Primates 31, 121-128.

Chiarello, A. G. (1994). Diet of the brown howler monkey Alouatta fusca in a semi-deciduous forest fragment of Southeastern Brazil. Primates 35, 25-34.

Chivers, D. (1994). Functional anatomy of the gastrointestinal tract. In Colobine Monkeys: Their Ecology, Behavior and Evolution, pp. 205-227 [J. Oates and G. Davies, editors]. New York, NY: Cambridge University Press.

Chivers, D. \& Hladik, C. (1980). Morphology of the gastrointestinal tract in primates: Comparisons with other mammals in relation to diet. Journal of Gut Morphology 166, 337-386.

Clapp, N. K. \& Tardif, S. D. (1985). Marmoset husbandry nutrition. Digestive Diseases and Sciences 30, 17S$23 \mathrm{~S}$.

Crissey, S. D. \& Allen, M. E. (1986). Feeding the captive gorilla. Proceedings of the American Association of Zoo Veterinarians: Chicago, llinois, pp. 40-43. Philadelphia, PA: AAZV.

Crissey, S. D., Edwards, M. S. \& Oftedal, O. T. (1989). The role of fiber in natural and manufactured diets of Red Howler monkeys (Alouatta seniculus). Proceedings of the Eighth Dr Scholl Conference on the Nutrition of Captive Wild Animals, pp. 135-147. Chicago: Lincoln Park Zoological Society.

Crissey, S. D., Feeser, T. \& Glander, K. (1995). Evaluation and reformulation of diets for captive Aye-aye (Daubentonia madagascariensis). Proceedings of the First Annual Conference of the Nutrition Advisory Group of the American Zoo \& Aquarium Association: Toronto Canada, pp. 172-179. Toronto: AZAA.

Crissey, S. D., Meehan, T., Pruett-Jones, M. A., Baker, A. \& Phillips, L. (1996). Vitamin D metabolites (1,25 dihydroxy D and 25 hydroxy D) in Goeldi monkeys (Callimico goeldi) and the incidence of renal disease. Symposium of The Comparative Nutrition Society 1, 33-36. 
Dierenfeld, E. (1993). Insects and feeding zoo animals in captivity. The Foods Insects Newsletter VI, no. 3. 112.

Edwards, M. S. (1995). Comparative adaptations to folivory in primates. Doctoral Dissertation, Michigan State University.

Ferrari, S. F. \& Martins, E. S. (1992). Gummivory and gut morphology in two sympatric callitrichids (Callithrix emiliae and Saguinus fuscicollis weddelli) from Westem Brazilian Amazonia. American Journal of Physical Anthropology 88, 97-103.

Flurer, C. I. \& Zucker, H. (1989). Ascorbic acid in a New World monkey family: species difference and influence of stressors on ascorbic acid metabolism. Zeitschrift für Emährungswissenschaft 28, 49-55.

Garber, P. A. (1984). Proposed nutritional importance of plant exudates in the diet of the Panamanian tamarin, Saguinus oedipus geoffroyi. International Joumal of Primatology 5, 1-13.

Garber, P. A. (1988). Foraging decisions during nectar feeding by tamarin monkeys (Saguinus mystax, Saguinus fuscicollis, Callitrichidae Primates) in Amazonian Peru. Biotropica 20, 100-106.

Garber, P. A. (1992). Vertical clinging, small body size, and the evolution of feeding adaptations in the Callitrichidae. American Journal of Physical Anthropology 88, 469-482.

Hartmann, E. W. \& Hartmann, J. (1991). Geophagy in moustached tamarins, Saguinus mystax and Saguinus fuscil (Platyrrhini: Callitrichidae), at the Rio Blanco, Peruvian Amazonian Peru. Primates 32, 533-537.

Heymann, E. W. (1992). Seed ingestion and gastrointestinal health in tamarins. Laboratory Primate Newsletter 31, 15-16.

Hollihn, U. (1973). Remarks on the breeding and maintenance of Colobus monkeys (Colobus guereza), Proboscis monkeys (Nasalis larvatus), and Douc langurs (Pygathrix nemaeus) in zoos. International Zoo Year Book 13, 185-188.

Kavanagh, M. (1983). A Complete Guide to Monkeys, Apes and Other Primates. London: The Oregon Press Ltd.

Kay, R. B. \& Davies, A. G. (1994). Digestive physiology. In Colobine Monkeys: Their Ecology, Behavior and Evolution, pp. 229-249 [J. Oates and G. Davies, editors]. New York, NY: Cambridge University Press.

Miller, B. \& Norman, A. (1984). Vitamin D. In Handbook of Vitamins: Nutritional, Biochemical, and Clinical Aspects, pp. 45-97 [L. Machlin, editor]. New York, NY: Marcel Dekker, Inc.

Milton, K. (1981). Food choice and digestive strategies of two sympatric primate species. The American Naturalist 117, 496-505.

Moreno-Black, G. S. \& Bent, E. F. (1982). The secondary compounds in the diet of Colobus angloensis. African Journal of Ecology 20, 29-36.

Morrissey, J., Rejchard, T., Janssen, D., Lloyd, M. \& Bernard, J. (1994). Vitamin D deficiency in Colobinae monkeys. Proceedings of the American Association of Zoo Veterinarians: Pittsburgh, Pennsylvania, pp. 381383. Philadelphia, PA: AAZV.

Muruthi, P. (1988). Food intake and energy expenditure among adult female baboons (Papio cynocephalus) in Amboseli National Park, Kenya. MSc Thesis, University of Nairobi.

Nash, L. T. (1989). Galagos and gummivory. Human Evolution 4, 199-206.

Nickel, D. A. \& Heymann, E. W. (1996). Predation on Orthoptera and other orders of insects by tamarin monkeys, Saguinus mystax mystax and Saguinis fuscicollis nigrifrons (Primate: Callitrichidae), in northeastern Peru. Journal of the Zoological Society of London 239, 799-819.

Nijboer, J. \& Dierenfeld, E. S. (1996). Comparison of diets fed to southeast Asian colobines in North American and European zoos, with emphasis on temperate browse composition. Zoo Biology 15, 499-507.

Norris, J. (1988). Diet and feeding behavior of semi-free ranging mandrills in an enclosed Gabonias forest. Primates 29, 449-463.

National Research Council (1978). Nutrient Requirements of Nonhuman Primates, no. 14. Washington, DC: National Academy of Sciences.

National Research Council (1989). Recommended Dietary Allowances, 10th ed. Washington, DC: National Academy of Sciences.

Oates, J., Swain, T. \& Zantovska, J. (1977). Secondary compounds and food selection by Colobus monkeys. Biochemical Systematics and Ecology 5, 317-321.

Oates, J., Waterman, P. \& Choo, G. (1980). Food selection by the South Indian leaf-monkey, Presbytis johnil, in relation to leaf chemistry. Oecologia $45,45-56$.

Oftedal, O. T. (1992). The nutritional consequences of foraging in primates: The relationship of nutrient intakes to nutrient requirements. In Foraging Strategies and Natural Diet of Monkeys, Apes and Humans, pp. 1-10 [A. Whiten and E. Widdowson, editors]. Oxford: Clarendon Press.

Oftedal, O. T. \& Allen, M. E. (1996). The feeding and nutrition of omnivores with emphasis on primates. In Wild Mammals in Captivity: Principles and Techniques, pp. 148-157 [D. Kleinman, M. Allen, K. Thompson, S. Lumpkin and H. Harris, editors]. Chicago and London: The University of Chicago Press.

Power, P. L. (1991). Digestive function, energy intake and the response to dietary gum in captive callitrichids. Doctoral Dissertation, University of California. 
Prema, T. P. \& Raghuramulu, N. (1994). Free vitamin $\mathrm{D}_{3}$ metabolites in cestrum diurnum leaves. Phytochemistry 37, 677-681.

Ramirez, M., Freese, C. H. \& Revilla, J. (1977). Feeding ecology of the pygmy marmoset, Cebuilla pygmaea in Northeastern Peru. In The Biology and Conservation of the Callitrichidae, pp. 91-104 [D. G. Kleinman, editor]. Washington, DC: SI Press.

Rosenberger, A. L. (1992). Evolution of feeding niches in New World monkeys. American Journal of Physical Anthropology 88, 525-562.

Sailer, L., Gaulin, S., Boster, J. \& Kurland, J. (1985). Measuring the relationship between dietary quality and body size in primates. Primates 26, 14-27.

Smith, C. C. (1977). Feeding behaviour and social organization in howling monkeys. In Primate Ecology, pp. 97-126 [T. H. Clutton-Brock, editor]. London: Academic Press.

Souci, S. W., Fachmann, W. \& Kraut, H. (1981). Food Composition and Nutrition Tables 1981/1982, 2nd ed. Stuttgart, Germany: Wissenschaftliche Verlagsgesslscrhaft.

Srivastava, A. (1991). Insectivory and its significance to Langur diets. Primates 32, 237-241.

Sterling, E. J., Dierenfeld, E. S., Ashbourne, C. J. \& Feistner, A. T. (1994). Dietary intake, food composition and nutrient intake in the wild and captive populations of Daubentonia madagascariensis. Folia Primatology 62, $115-124$.

Stevens, C. \& Hume, I. (1995). Comparative Physiology of the Vertebrate Digestive System, 2nd ed. New York, NY: Cambridge University Press.

Stewart, C. S., Fonty, G. \& Gouet, P. (1988). The establishment of rumen microbial communities. Animal Feed Science and Technology 21, 69-97.

Struhsaker, T. T., Cooney, D. O. \& Siex, K. S. (1997). Charcoal consumption by Zanzibar Red Colobus monkeys: its function and its ecological and demographic consequences. International Journal of Primatology 18, 61-72.

Takahashi, N., Suda, S., Shinki, T., Horiuchi, N., Shiima, Y., Tankoka, Y., Koisumi, H. \& Suda, T. (1985). The mechanisms of end-organ resistance to 1-alpha, 25 dihydroxycholecalciferol in the common marmoset. Biochemical Journal 227, 555-563.

Terborgh, J. (editor) (1983). In Five New World Primates: A Study of Comparative Ecology. Princeton, NH: Princeton University Press.

United States Department of Agriculture (1984). Agricultural Handbook, no. 8-11: Vegetables and Vegetable Products. New York: Dover Publications Inc.

Van Soest, P. J. (1996). Allometry and ecology of feeding behavior and digestive capacity on herbivores: A review. Zoo Biology 15, 445-479.

Waterman, P. \& Kool, K. (1994). Colobine food selection and plant chemistry. In Colobine Monkeys: Their Ecology, Behavior and Evolution, pp. 205-227 [G. Oates and J. Davies, editors]. New York, NY: Cambridge University Press.

Watkins, B. E., Ullrey, D. E. \& Whetter, P. A. (19985). Digestibility of a high-fiber biscuit diet by black and white Colobus (Colobus guereza). American Journal of Primatology 9, 137-144.

Whitten, P. (1988). Effects of patch quality and feeding subgroup size on feeding success in vervet monkeys. Behavior 105, 35-52.

Williamson, E., Tutin, C., Rogers, M. \& Fernendez, M. (1990). Composition of the diet of lowland gorillas in Lope in Gabon. American Journal of Primatology 21, 265-277.

Windholz, M. (editor) (1976). In Merck Index: An Encyclopedia of Chemicals and Drugs, 9th ed. Rahway, NJ: Merck \& Company, Inc.

Wrangham, R. \& Goodall, J. (1989). Chimpanzee use of medicinal leaves. In Understanding Chimpanzees, pp. 25-35 [P. G. Helthne and L. Marquardt, editors]. Cambridge, MA: Harvard University Press.

Yeager, C. P., Silver, S. C. \& Dierenfeld, E. S. (1997). Mineral and phytochemical influences on foliage selection by the proboscis monkey (Nasalis larvatus). American Joumal of Primatology 41, 1117-1128. 